\title{
A clinical study of McIndoe vaginoplasty in vaginal agenesis
}

\author{
Samarina Kamal ${ }^{1 *}$, Sarita Tirkey $^{2}$, Shashibala Singh $^{2}$, Shobha Chakraborty ${ }^{2}$
}

\begin{abstract}
${ }^{1}$ Department of Obstetrics and Gynaecology, Alam Hospital and Research Centre Pvt. Ltd., Ranchi, Jharkhand, India ${ }^{2}$ Department of Obstetrics and Gynecology, RIMS, Ranchi, Jharkhand, India
\end{abstract}

Received: 23 October 2019

Revised: 18 November 2019

Accepted: 22 November 2019

\author{
*Correspondence: \\ Dr. Samarina Kamal, \\ E-mail: drsamrinakamal@gmail.com
}

Copyright: (c) the author(s), publisher and licensee Medip Academy. This is an open-access article distributed under the terms of the Creative Commons Attribution Non-Commercial License, which permits unrestricted non-commercial use, distribution, and reproduction in any medium, provided the original work is properly cited.

\begin{abstract}
Background: The aim of this study is to determine the effectiveness of McIndoe Vaginoplasty in the creation of a neovagina for patients with vaginal agenesis.

Methods: this is a retrospective study of 50 cases of vaginal agenesis, who underwent McIndoe Vaginoplasty over a period of 8 years (2004-2012) by using skin graft in 25 cases and amnion as graft in the remaining.

Results: McIndoe Vaginoplasty was performed successfully in all 50 patients and post-surgical result was acceptable to the patient psychologically, sexually and aesthetically.

Conclusions: McIndoe Vaginoplasty is a safe and effective procedure for providing a satisfactory and functional vagina in patients with MRKH syndrome.
\end{abstract}

Keywords: Fetal distress, Hypertension in pregnancy, Stillbirths

\section{INTRODUCTION}

Vaginal agenesis is present in one among 4000 to 10000 female births. ${ }^{1}$ Vaginal agenesis may occur as an isolated abnormality. $^{2}$ It is most commonly associated with Mayer- Rokitansky- Kuster- Hauser Syndrome and Androgen Sensitivity Syndrome. ${ }^{1}$

Type I MRKH syndrome is characterized by an isolated absence of the proximal two-thirds of the vagina, whereas Type Ilis marked by other malformations- vertebral, cardiac, urologic and otological anomalies. ${ }^{3}$ The ovarian function in these patients is normal. Patients with MRKH syndrome are phenotypically and genotypically females with 46XX karyotype.

Patients with vaginal agenesis are often diagnosed late when they present with i. Primary amenorrhoea, ii. Married females with failure of consummation of marriage, iii. Third group was infertility. If it is left untreated, there will be sexual inability and patients may develop severe psycho- logical problems. ${ }^{4}$ There are several nonsurgical and surgical techniques describe in the literature for treatment of vaginal agenesis. ${ }^{5}$ Nonsurgical options include vaginal dilatation with dilator, while surgical options include numerous procedures described for creation of neo-vagina with acceptable function, feeling and appearance, they include Frank Serial dilation, Abbe Wharton Mc Indoe's technique, Vecchietti's technique, Sigmoid or ileal flaps, Gracilis flap, Singapore flap, Expanded vulval flap. ${ }^{6-9}$ Abbe McIndoe procedure in which split thickness skin graft is used to cover a stent into a surgically created space between the bladder and rectum is the simplest and most popular vaginal reconstruction surgery. ${ }^{10}$

There are different modifications of the Abbe McIndoe procedure either using skin graft from thigh or amnion. The surgical management of vaginal agenesis is a great technical challenge, the aim being to provide a vagina of an appropriate length, adequate calibre and with aesthetic 
acceptance. The important steps that need to be highlighted include: creating an adequate sized neovagina, resurfacing the lining by split thickness skin graft and putting an improvised mould. Objective was to study the result of modified McIndoe's technique of vaginal reconstruction with respect to vaginal length and complications in patient with vaginal agenesis.

\section{METHODS}

Statistically 50 patients aged 18-26 years underwent modified McIndoe Vaginoplasty over a period of 8 years (2008-2016). The indications of McIndoe Vaginoplasty in all the cases was congenital vaginal agenesis. Those who had short vagina which could be lengthened were excluded from this study. All had primary amenorrhea, normal secondary sex characteristics and a vaginal dimple without vaginal orifice. All patients underwent routine investigations including USG (KUB) to rule out major renal anomalies and karyotyping. Out of these, 3 had renal anomalies. All patients were followed for about 6 months.

Amniotic membranes were obtained under sterile conditions from elective Caesarean deliveries after screening the mothers for Hepatitis B and C and HIV. Vaginoplasty was performed under GA using amnion graft in 25 cases (Group A) and split thickness skin graft in the other 25 cases (Group B).

\section{Creating neovaginal space}

Under GA the patient was placed in the lithotomy position and a transverse incision is made through the vaginal vestibule. The space between the urethra and bladder anteriorly and the rectum posteriorly is dissected until under surface of the peritoneum is reached while carefully palpating the catheter in front and the rectum, under surface of the peritoneum is reached while carefully palpating the catheter in front and assistant's finger behind.

A cavity size of depth $10-12 \mathrm{~cm}$ in length and a diameter of $4-5 \mathrm{~cm}$ were achieved. Meticulous hemostasis is achieved to keep the vaginal cavity dry beneath the graft.

\section{Preparing the vaginal form}

In first 25 cases, a vaginal mould made with $50 \mathrm{ml}$ syringe wrapped with foam covered with latex condom and sterilized in cidex solution was then wrapped with freshly obtained amnion facing inwards and placed in the neovaginal space. The amnion graft was fixed to the mould by suturing the edge of amnion to the mould.

In the remaining 25 cases, split thickness graft of approximate 4.8 inches and 0.018 inch was obtained using skin grafting handle or dermatome from the lateral aspect of upper thigh. The graft was wrapped around the previously described mould. The two margins of graft were sutured with 3-0/ 4-0 non-reactive sutures. After the form has been placed in the neovaginal space, the edges of the graft are sutured to the skin edge with 3-0 absorbable sutures.

The labia majora was then sutured together loosely with silk sutures to hold the mould in position and $\mathrm{T}$ bandage applied. The Foley catheter was maintained for 1 week postoperatively and patient was kept head low and on low residue diet for 5 days. Prophylactic antibiotic was given for 7 days post operatively.

\section{Replacing with a new form}

The mold was removed after cutting labial stitches and vaginal cavity was irrigated with warm saline solutions and inspected. The cavity should be inspected carefully. The graft was retained and well taken invariably in all cases. Vaginal douching was done with povidone iodine and second mould made with $20 \mathrm{ml}$ syringe or candle was kept in place.

Patients were counselled about the method of placement and removal and washing of mould made with $20 \mathrm{ml}$ syringe or candle was kept in place. Patients were counselled about the method of placement and removal and washing of mould for 3 months continuously followed by insertions only at night for the next 3 months to prevent contraction. Physical relation was allowed after 3 months in married women.

\section{RESULTS}

The operation time ranged from 20-45 minutes in case of amnion graft and 1-1.5 hours in case of skin graft covered mould. Most of studies reported a high success rate of McIndoe's procedure anatomically and functionally which varied from $75 \%$ in some series up to $100 \%$ in other studies which can be seen in this study too (Table 1).

Table 1: Result of McIndoe vaginoplasty in terms of success rate.

\begin{tabular}{|lll|}
\hline Outcome & $\begin{array}{l}\text { Result } \\
\text { (in term of graft take) }\end{array}$ & No. of cases \\
\hline Excellent & $(90-100 \%)$ & 46 \\
\hline Good & $(75-90 \%)$ & 04 \\
\hline Poor & $(<75 \%)$ & 00 \\
\hline
\end{tabular}

None of the 50 cases had any significant post-operative complications. Clinical examination performed post operatively revealed neovagina of adequate length and calibre. Amnion graft was taken completely in all 25 cases of group A without any evidence of infection or granulation tissue formation. In group B, 4 patients had evidence of partial rejection with foul smelling discharge and granulation tissue formation (Table 2). 
Table 2: Complications of McIndoe Vaginoplasty in Group A and Group B.

\begin{tabular}{|lll|}
\hline Complications & $\begin{array}{l}\text { Group A } \\
\text { Amnion } \\
\text { graft }\end{array}$ & $\begin{array}{l}\text { Group B } \\
\text { (Split thickness } \\
\text { skin graft) }\end{array}$ \\
\hline $\begin{array}{l}\text { Immediate } \\
\text { complications }\end{array}$ & 02 & 02 \\
\hline Bleeding & 00 & 00 \\
\hline Rectal injury & 04 & 00 \\
\hline Late complications & 02 & 02 \\
\hline Infection & 01 \\
\hline $\begin{array}{l}\text { Partial vaginal } \\
\text { stenosis }\end{array}$ & 00 & 01 \\
\hline $\begin{array}{l}\text { Granulation tissue } \\
\text { formation }\end{array}$ & 00 & - \\
\hline $\begin{array}{l}\text { Prolonged non- } \\
\text { infective discharge }\end{array}$ & 00 & - \\
\hline Rectovaginal fistula & - & - \\
\hline Vesicovaginal fistula & - & - \\
\hline Vesicovaginal fistula & - & - \\
\hline Failure of graft take & - & 02 \\
\hline Sinus formation & - & \\
\hline $\begin{array}{l}\text { Skin donor site } \\
\text { Complications }\end{array}$ & 00 & 0 \\
\hline
\end{tabular}

\section{DISCUSSION}

Out of these techniques, modified McIndoe's vaginoplasty so far represents the simplest one with least morbidity and is the procedure of choice. ${ }^{11}$ This low morbidity is also supported by the result where patient reported no complication that needed surgical intervention or a complication that has long term sequel. Regarding anatomical aspect the average size of the vagina that obtained in study was $6 \mathrm{~cm}$ in length and 2 to $3 \mathrm{~cm}$ diameter, which is approximately the same as it was in other studies, using the same technique, and in this case the dimension of new vagina was approximately similar to that of normal vagina. ${ }^{12}$ There are various methods for surgically constructing neovaginas and the difference among the various surgical approaches lies in the tissues used to line the neovagina.

Amnion as graft for vaginoplasty was deemed superior to skin graft because of:

- Unlimited and ready availability

- Its antimicrobial properties reduce the risk of infection

- Amnion does not express HLA- A,B or DR antigens, hence immunologic rejection does not occur

- Lack of scarring at skin grafting site

- $\quad$ Reduces the time and cost of surgery as compared to preparation of skin graft

- Reduces duration of hospital stay, 10-12 days with amnion graft as against 1 month due to morbidity of skin donor site
- Antifibroblastic activity and cell migration/ growth promoting activity promotes epithelialization and graft take up

- $\quad$ Less emotional stress and better result. ${ }^{13}$

Compared to dilatation methods, vaginoplasty is quicker and result oriented while with dilatation techniques, patient compliance and long term follow-up pose a challenge although dilatation methods are definitely simpler and non-invasive.

Most patients who were married and came for follow-up after marriage reported aesthetic and sexual satisfaction but some of them complained of vaginal dryness and lack of lubrication with sexual intercourse.

Hence, McIndoe's vaginoplasty is one of the most popular surgeries for vaginal agenesis. The result and complications of this study are comparable to other studies. Parikh reported partial rejection of skin graft in 15 out of 29 cases. ${ }^{14}$ Partial rejection of graft can lead to formation of granulation tissue, fibrosis and obliteration of the neovaginal. Post-operative use of mould is the mainstay of surgery. Hojsgaard reported three cases of vaginal contracture out of $26 .^{15}$ Another study by Fotopoulou et al, conducted in Germany in 2009 on 7 patients had success rate of $85 \%$ with 1 patient having major operative complication. ${ }^{16}$

\section{CONCLUSION}

Present findings suggest that the modified Mc Indoe's technique is a simple, effective procedure for the treatment of vaginal agenesis, but proper mould usage after surgery remains the cornerstone of the treatment. The use of amnion graft in vaginoplasty can reduce the operative time, hospital stay and simplify the procedure.

Funding: No funding sources

Conflict of interest: None declared

Ethical approval: The study was approved by the Institutional Ethics Committee

\section{REFERENCES}

1. Saraf S, Saraf P. McIndoe Vaginoplasty: revisited. Internet J Gynecol Obstetr. 2007;6(2).

2. Practice committee of the American society for reproductive medicine, Current evaluation of amenorrhea. Fertil Steril. 2008 Nov;90(5 Suppl):S219-25.

3. Griffin JE, Edwards C, Madden JD, Harrod MJ, Wilson JD. Congenital absence of the vagina: the Mayer-Rokitansky-Kuster-Hauser syndrome. Annals Int Med. 1976 Aug 1;85(2):224-36.

4. Dixon D, Wali F, Hail S, Welch R, Davis G. Treatment of vaginal aplasia among afghan women with the mcindoe vaginoplasty. Female Pelvic Med Reconstructive Surg. 2010 May 1;16(3):179-87. 
5. Bastu E, Akhan SE, Mutlu MF, Nehir A, Yumru H, Hocaoglu E, et al. Treatment of vaginal agenesis using a modified Mc Indoe's Technique-long tern follow up of 23 patients and literature review. Can J Plast Surg. 2012;20(4):241-4.

6. Karim RB, Hage JJ, Dekker JJM, Schoot CMH. Evolution of the methods of neo-vaginoplasty for vaginal aplasia. Eur J Obstet, Gynecol Reprod Biol. 1995;58:19-27.

7. Wesley JR, Coran AG. Intestinal vaginoplasty for congenital absence of the vagina. J Pediatr Surg. 1992;27(7):885-9.

8. McCraw JB, Massey FM, Shanklin KD, Horton CE. Vaginal reconstruction with gracilis myocutaneous flaps. Plast Reconst Surg.1976;58:176-83.

9. Okada E, Iwahira Y, Maruyama Y. Treatment of vaginal agenesis with an expanded vulval flap. Plast Reconstr Surg. 1996;98(3):530-3.

10. Vesanovi'c S, Panajotovi'c L, Garaleji'c E. Sensibility of vagina reconstructed by McIndoe's method in Mayer- Rokitansky-Küster-Hauser syndrome. Vojnosanit Pregl. 2008;65(6):449-55.

11. Abbe R. New method of creating a vagina in case of congenital absence. Med Rec (NY). 1898;54:836-8.
12. Frost-Arner L, Åberg M, Jacobsson S. Split skin graft reconstruction in vaginal agenesis: a long-term follow-up. Scandinavian J Plast Recons Surg Hand Surg. 2004 Jan 1;38(3):151-4.

13. Chohan A, Burr F, Mansoor H, Falak T. Amnion graft in vaginoplasty- an exprtience at 3 teaching hospitals of Lahore. Biomedica. 2006; 22 (1): 21-4.

14. Parikh MN. Congenital absence of vagina: MRKH syndrome. J Obstet Gynecol India. 2000;50:128-38.

15. Hojsgaard A, Villadsen I. McIndoe procedure for congenital vaginal agenesis; complications and results. Br J Plast Surg 1995; 48: 97-102.

16. Fotopoulou C, Sehouli J, Gehrmann N, Schoenborn I, Lichtenegger W. Functional and anatomic results of amnion vaginoplasty in young women with Mayer-Rokitansky-Küster-Hauser syndrome. Fertil Steril. 2010 Jun 1;94(1):317-23.

Cite this article as: Kamal S, Tirkey S, Singh S, Chakraborty S. A clinical study of McIndoe vaginoplasty in vaginal agenesis. Int J Reprod Contracept Obstet Gynecol 2019;8:4732-5. 